\title{
REVIVAL JUDGMENTS UNDER THE FULL FAITH AND CREDIT CLAUSE
}

Many state judiciaries have displayed a continuing resistance to the Supreme Court's interpretation of the full faith and credit clause. ${ }^{x}$ Their major objection stems from that Court's insistence that a judgment of one state be given effect in all sister states irrespective of the fact that the judgment could not have been obtained in the state where enforcement is sought because inconsistent with, or repugnant to, the public policy of that state. ${ }^{2}$ The only concession made permits the forum to ignore foreign procedure and apply its own.

In the leading case of $M c$ Elmoyle v. Cohen, 3 the Supreme Court classified the problem of the applicability of the forum state's statute of limitations to foreign judgments as one of procedure, since such judgments were said to affect only the remedies of the foreign judgment holder. 4 The forum could therefore apply its own statute of limitations to deny enforcement of a foreign judgment although the judgment would not be so barred in the state of its origin.

Relying on the McElmoyle doctrine, the Supreme Court of Missouri in Union National Bank v. Lamb5 refused enforcement to the holder of a dormant I927 Colorado judgment that had been revived by a I945 Colorado proceeding. The denial was predicated on Missouri's ten-year statute of limitations, under which a 1927 Missouri judgment could not have been revived in I945. In reversing the decision, the United States Supreme Court assumed that the Colorado revival action resulted in a new judgment and was consequently entitled to full faith and credit in Missouri. ${ }^{6}$ Justice Frankfurter dissented on the ground that, under Colorado law, a revival proceeding possibly did not result in a new judgment, but was effective only to extend the statutory period in which to enforce the original I927 Colorado judgment. In such a case the Missouri action would clearly be barred by the Missouri statute of limitations.

But for stare decisis there seems little reason why the classification of problems of limitation under the McElmoyle rule should persist today. While it is true that it would be cumbersome for a court to conform to all minute proce-

I.S. Const. Art. $4, \S \mathrm{I}$.

2 Fauntleroy v. Lum, 2xo U.S. 230 (Ig08), where it was held that a Mississippi court had not given full faith and credit to a Missouri judgment when it refused to enforce it because based on a Mississippi gambling contract which was both void and illegal in that state. Aside from the bar of the statute of limitations, the only defenses available in an action on a judgment of a sister state are proof of "extrinsic" fraud and lack of jurisdiction. Concerning "extrinsic" fraud, see Cole v. Cunningham, I33 U.S. xo7 (189o). As to jurisdictional requirements generally, see Milliken v. Meyer, 3 II U.S. 454 (I940).

${ }^{3}$ I3 Pet. (Uं.S.) 3 I2 $_{2}$ (1839).

4 The Court partially based its decision upon the much broader rationale that state sovereignty provided courts the right to apply law in accordance with notions of policy existing in the forum. I3 Pet. (U.S.) 3I2, 327 (I839). This argument has been clearly repudiated by the United States Supreme Court in Fauntleroy v. Lum, 2I0 U.S. 230 (Ig08).

${ }^{5} 358$ Mo. 65 , 2r3 S.W. 2 d 416 (I948).

${ }^{6}$ Union National Bank v. Lamb, 336 U.S. 901 (I949). 
dural devices of a foreign jurisdiction, the application of a foreign statute of limitations does not present the same difficulty. Such statutes are easily established and applied, whether of local or foreign origin. It is also difficult to conceive how a right remains unaffected when a remedy is denied, unless one can understand the language of "immortal" rights to bring "eternally prohibited" actions. ${ }^{7}$ In view of continued Supreme Court pronouncements that judgments of sister states must be given the same effect as they would receive within the rendering jurisdiction, future modification or abandonment of the McElmoyle rule would not be surprising.

Despite these criticisms of the rule and despite evident Supreme Court hostility, local statutes of limitations have been constantly applied to bar actions upon foreign judgments. The present case may be viewed as an attempt by the Missouri court to extend such application. Two provisions of the Missouri limitations statute are relevant. The first limited the life of a judgment, whether domestic or foreign, to ten years after its original rendition or ten years after its revival. The second provided that no judgment could be revived after ten years from its rendition. If the I945 Colorado revival judgment is considered a "new" judgment, it is patent, of course, that it was well within the ten-year limitation provided by the first provision and could not have been barred under the traditional application of the McElmoyle rule. However, the 1945 Colorado proceeding was based on an eighteen year old judgment. Its revival under a twenty-year Colorado revival limitation was plainly inconsistent with the policy of Missouri's ten-year revival limitation contained in the second provision. In holding that the I945 revival judgment was unenforceable because the revival proceeding would not have been possible under Missouri's ten-year limitation, the Missouri court sought to extend the $M c E$ Elmoyle rule by construing it so as to bar an action on a foreign judgment which was based on a cause of action which would have been barred by local limitation. These examinations of the age of a cause of action underlying the judgment sought to be enforced are of course violative of the principle that the state where enforcement is sought cannot look behind the judgment, and for this reason have been repeatedly struck down by the Supreme Court.8

7 Ames, Lectures and Legal History I99 (rgr3). The traditional view of regarding problems of limitations of actions as procedural is no longer regarded with favor. Its results are now being avoided by a variety of devices, especially by borrowing statutes and by means of the judge-made theory of regarding as "substantive" time limitations of the lex causae which either "destroy" the right in question or are contained in a statute referring to a right which is itself a statutory creation. See Robertson, Characterization in the Conflict of Laws 248 (r940); Stumberg, Conflict of Laws I4I (r937); Limitations-Are They Properly Viewed as Procedural in Conflicts Problems, 79 U. of Pa. L. Rev. III2 (I93I); also a comment by Perkins to be published in the forthcoming issue of the La. L. Rev.

${ }^{8}$ Roche v. McDonald, 275 U.S. 449 (I927) (Washington Supreme Court was reversed for refusing to enforce an Oregon judgment which was based on a Washington judgment which had been barred by the Washington statute of limitations); Christmas v. Russell, 5 Wall. (U.S.) $29 \circ$ (1866) (Mississippi statute providing that no action could be maintained against a resident on any judgment obtained outside the jurisdiction when the cause of action on which it was based would have been barred by limitation in Mississippi, was held unconstitutional). 
Trite as the decision in the principal case may seem as an application of wellknown law, it is interesting from another standpoint. For brevity's sake assume state $F_{x}$ to be the state rendering a revival judgment and state $F_{2}$ as the state in which enforcement is sought; assume, furthermore, that the period of limitations which $F_{2}$ will apply to an action on judgments is shorter than the period within which $F_{x}$ permits a judgment to be revived. Now if, as in the Union National Bank case, $F_{I}$ 's revival judgment must be given full faith and credit in $F_{2}$ despite the fact that $F_{2}$ 's statute of limitations would have barred enforcement of the original $F_{\mathrm{x}}$ judgment at the time of revival, it is apparent that the effect of the $F_{\mathrm{x}}$ revival is to set a new period of limitations running in all possible $F_{2}$ jurisdictions. Thus an $F_{\mathrm{I}}$ judgment creditor may avoid the traditional $M c E L-$ moyle rule by first obtaining a revival judgment in $F_{\mathrm{x}}$.

There are, however, two prerequisite conditions which must exist before the holder of an $F_{x}$ judgment can be successful in such an avoidance. The first is dependent upon the $F_{x}$ jurisdiction's conception of a revival judgment. This is so because, before the $F_{\mathrm{I}}$ revival can be considered to toll the running of a new statute of limitations in $F_{2}$ jurisdictions, it must appear that $F_{1}$ conceived of its revival judgment as a "new" judgment, rather than one which merely extended the statutory period in which the creditor would be allowed to enforce his original judgment. If the revival judgment merely extends the statutory period of limitation in $F_{1}$, it will have no effect in extending $F_{2}$ 's period and the

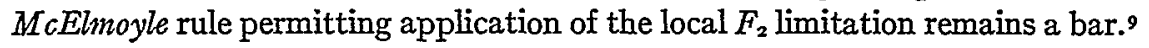
However, if the $F_{\mathrm{r}}$ revival has those attributes which cause it to be considered a "new" judgment, the rule of the principal case insists on full faith and credit in $F_{2}$ 's courts despite $F_{2}$ 's statute.

Thus there arises the question of determining when a revival constitutes a "new" judgment and when it merely gives the original judgment a "new lease on life." The answer depends on which one or more of the four more common procedural devices are permitted by the $F_{x}$ jurisdiction, and which of these devices are chosen by the judgment holder. The two traditional means are the writ of scire facias and the action of debt. Statutes also allow revival either by motion or by formal suit.

(I) In a number of states the writ of scire facias disappeared with the advent of the codes; but where it continues to exist it serves its old purpose though not always with the same effect. Historically the writ was not regarded as an original proceeding but as an additional remedy to aid in recovering the original judgment debt. ${ }^{\text {Io }}$ If the debtor failed to show payment or discharge, the writ's

9 Owens v. Henry, I6r U.S. $64^{2}$ (1896); Collins County National Bank v. Hughes, rro Tex. 362,220 S.W. 767 (r920).

ro See LaFayette v. Wonderly, 92 Fed. $3{ }^{\mathrm{I}} 3$ (I899); 3 Bl. Comm. * ${ }_{42 \mathrm{I}}$; Freeman, A Treatise of the Law of Judgments $\S$ rogI (r925). The writ of scire facias had its origin in the Statute of Westminster II, I3 Ed. I, c. 45 (I272), which provided that the issuance of the writ was necessary to permit an execution on a judgment which had stood for more than a year and a day. It has been adopted in the United States either by statute or as part of the common law. 
effect was to reinstate the old judgment. ${ }^{\mathrm{x}}$ In accordance with the historical pattern, most jurisdictions consider the proceeding as a continuation of a former suit." Some, however, treat it as a new action giving rise to a "new" judgment.13 (2) The action of debt brought on the original judgment, on the other hand, has always been considered an initial proceeding giving rise to a "new" judgment. Though its primary and traditional purpose was the collection of the debt evidenced by the judgment, it also was used as a means of revival. Under the codes, actions in the nature of an action of debt can still be brought for revival purposes, ${ }^{14}$ and in some jurisdictions this means of revival is expressly authorized by statute. ${ }^{x_{5}}$ (3) In other jurisdictions revival may be had upon motion before the court, but the judgment debtor must be given reasonable notice and an opportunity to offer such defenses as payment or discharge. ${ }^{16}$ The general rules of procedure on motions are held to apply and the effect is merely to reinstate the enforceability of the old judgment. ${ }^{x 7}$ (4) Either in addition to or in exclusion of these various methods, many states provide for revival by a formal suit for that purpose, similar to any other action at law and subject to the same requirements. ${ }^{x 8}$ The proceedings have been considered to result in a new and independent judgment in some jurisdictions, while in others their effect is merely to reinstate the original judgment.

However, the classification of these various types of revival judgments is not always so clear as is indicated by Justice Frankfurter's dissent in the principal case. Since the problem is of little importance when the revival judgment is sought to be enforced in $F_{x}$ the matter is seldom discussed. Often an answer must be surmised from an occasional dictum in some decision. Another interesting question is whether the classification given by $F_{x}$ courts is binding upon those of $F_{2}$, or whether the courts of $F_{2}$ can make an independent examination. $F_{\mathrm{r}}$ decisions in similar situations have not always been accepted in foreign jurisdictions. ${ }^{19}$ Although the problem was not raised, the opinions in the Union National

"2 See LaFayette v. Wonderly, 92 Fed. 313 (I899); Freeman, A Treatise of the Law of Judgments \& rogI (r925).

Iz Trustees of Schools v. Chamberlin, 334 Ill. App. 83, 78 N.E. 2d 525 (r948); Collins County National Bank v. Hughes, I Io Tex. 362, 220 S.W. 767 (I920); Freeman, A Treatise of the Law of Judgments § IogI (I925); see Annotation, I44 A.L.R. 403 (1943).

${ }^{23}$ Browne v. Chavez, I8I U.S. 68 (I90); Freeman, A Treatise of the Law of Judgments 8 IIOT (I925).

${ }_{4}$ Industrial National Bank v. Shalin, 33 o Ill. App. 498, 72 N.E. 2 d 52 (I947).

${ }^{15}$ Fo example, see Tex. Ann. Rev. Civ. Stat. (Vernon, r94 I) art. 5532.

${ }^{16}$ Richardson v. Barnhart, I96 Okla. I00, I62 P. 2 d I02I (I945); Shefts v. Oklahoma Co., r92 Okla. 483 , I37 P. 2 d 589 (r943).

${ }_{77}$ Shefts v. Oklahoma Co., $x_{92}$ Okla. 483 , I37 P. 2d 589 (I943).

${ }_{28}$ Trustees of Schools v. Chamberlin, 334 IIl. App. 83,78 N.E. $2 \mathrm{~d} 525$ (I948); Tingwall v. King Hill Irrigation Dist., 66 Idaho 77, I55 P. 2 d 605 (I945); Ill. Rev. Stat. (I949) c. IIO, $\S \mp 79$.

19 Compare McArthur v. Md. Casualty Co., I84 Miss. 663, 69o, 186 So. 305, 3 Io (I939), dissenting opinion by Chief Justice Smith; see also I Rabel, Conflict of Laws 47 (I945). 
Bank case obviously proceed on the basis that an $F_{\mathbf{x}}$ determination is conclusive.

The second prerequisite for enforcement of the "revived" judgment in another state is that the court entertaining the revival action must be able to obtain jurisdiction over the defendant. If the proceeding is a new action and its purpose is to obtain a new personal judgment against the defendant, the requirements of due process are the same as in any other action in personam. ${ }^{20} \mathrm{~A}$ judgment which requires enforcement outside the state in which it was rendered normally involves a nonresident, and a judgment creditor will, therefore, be forced to wait until the defendant makes an appearance within the jurisdiction. In the Union National Bank case the defendant was served with process outside of Colorado. Since such notification is said to be no more effective than service by publication, ${ }^{2 x}$ it would appear that the Missouri court could have avoided reversal by placing its decision on the ground that the Colorado court granting the revival judgment failed to acquire jurisdiction over the defendant, assuming that at the time the revival proceedings were commenced, the defendant was not a domiciliary of Colorado. ${ }^{22}$ Where, however, the proceeding is considered to be a mere continuation of the former suit which does not result in a new judgment, personal service within the reviving jurisdiction is not required, since jurisdiction over the parties is said to continue from the original action. ${ }^{23}$

It would be unfortunate if it became settled law that a judgment creditor's rights must hinge upon a distinction between "new" and "continued" actions which has resulted from purely formalistic tests and has been elaborated for purposes different from that of determining whether or not a "stale" judgment shall be enforced in another state. Either the much criticized McElmoyle case should be overruled and all revived foreign judgments should be required to be given the same effect as they would receive in $F_{1}$, or the courts of $F_{2}$ should be allowed to refuse enforcement to any revival judgment once the original judgment on which it was based is barred by the $F_{2}$ statute of limitations. Inasmuch as the rule of the $M C E$ Elmoyle case is already subject to a great number of exceptions and in view of the present trend toward giving the full faith and credit clause a more meaningful interpretation, the first alternative would appear more desirable. Either solution would be preferable to that which seems to follow from the principal case and which makes $F_{2}$ 's duty of enforcement depend upon the historical accident of the "new" and "continued" judgment distinction and upon the fortuitous choice of revival procedure adopted by the judgment

${ }^{20}$ Owens v. Henry, I6I U.S. 642 (I896); Collins County National Bank v. Hughes, Iro Tex. 362,220 S.W. 767 (I920).

${ }^{2 \pi}$ Roller v. Holly, 176 U.S. 398 ( 1899 ). By statute in Illinois, notification outside the state is given the same force and effect as service by publication. Ill. Rev. Stat. (I949) c. Iro, \& I40.

22 Milliken v. Meyer, 3 rr U.S. 454 (r940).

23 Bank of Edwardsville v. Rafiaelle, 38I Ill. 486, 45 N.E. 2d 65I (r942). For a collection of authorities on this point, see Annotation, I44 A.L.R. 403 (1943). 
creditor. Whichever solution will finally be chosen, care ought to be taken that no revival judgment be enforced unless the judgment debtor was sought to be informed of the revival proceedings in a manner reasonably calculated to notify him of the pending proceedings.

\section{THE SEARCH FOR "REASON AND EXPERIENCE" UNDER THE FUNK DOCTRINE}

"[A] wife cannot be produced either against or for her husband, 'quia sunt duae animae in carne una." " So spoke Coke of the common-law principle. "[T]here is none now so poor as to do it reverence." So spoke Judge Clark of the same principle in United States v. Walker. ${ }^{2}$ But his was the dissent, and the majority opinion by Judge Learned Hand upheld one-half the principle, though not the Latin, so that it was reversible error to allow a wife to testify against her husband.

Walker was convicted of transporting in interstate commerce money "taken feloniously by fraud with intent to steal or purloin." 3 After having gone through the form of marrying the complainant, one Mary Asche, when he was already married to another, he obtained two large sums of money from her and absconded to New York. On previous occasions he had victimized his wife and another woman in much the same manner, and the trial court admitted the testimony of these two ladies on the issue of Walker's fraudulent intent in the crime charged. In reversing the district court, Judge Hand retained the common-law rule that the husband has a privilege to prevent his wife from testifying against him. ${ }^{4}$ Hand felt that before this rule be overthrown, the court must "await the choice of Congress between the conflicting interests involved, or such an overwhelming general acceptance by the states of abolition of the privilege, as induced the Supreme Court to action in Funk v. United States." Judge Clark, dissenting vigorously, called for the abolition of the privilege as accomplished by another federal court of appeals. ${ }^{6}$ Even more emphatically did he denounce the majority's refusal to broaden the common-law doctrine of "necessity," a doctrine which permitted a wife who had suffered personal wrongs at her husband's hands to testify against him. Clark saw reason as requiring the extension of this exception to the case where the wife, though not the actual complainant, is yet desirous of testifying to a "Chinese copy" of the offense charged. He felt the majority had not faced modern realities in the spirit invoked in the Funk case

$\therefore$ Co. Litt. ${ }^{*} 6 \mathrm{~b}$.

${ }^{2}{ }_{7} 6$ F. 2 d 564, 569 (C.A. 2d, I949), cert. den. 338 U.S. 89 I (I949).

348 Stat. 794 (I934) and 53 Stat. II78 (r939), I8 U.S.C.A. $\$ 4 \mathrm{r}_{5}$ (Supp. r948), revised 62 Stat. 862 (1948), I8 U.S.C.A. \& 2314 (1948).

48 Wigmore, Evidence $\$ \$ 2227-28$ (1940).

5 United States v. Walker, note 2 supra, at 568 .

6 Yoder v. United States, 80 F. 2d 665 (C.C.A. Ioth, I935). 